\title{
Taman Baca Masyarakat "Tholabul'ilmi" Sebagai Sarana Meningkatkan Literasi Desa Panduman Kecamatan Jelbuk
}

\author{
Menik Chumaidah $^{1}$, Abdul Jalii ${ }^{2 *}$, Cahya Tribagus Hidayat ${ }^{3}$ \\ ${ }^{1,3}$ Universitas Muhammadiyah Jember \\ ${ }^{2}$ Universitas Jember \\ 2abduljali1290395@gmail.com
}

\begin{abstract}
Literacy is the ability to access, understand, and use something intelligently through various activities, including reading, listening, writing and speaking. The purpose of choosing the provision of community reading parks is that to see from the reading interest of the Panduman community is very minimal, especially among adolescent and children communities. An example is the existence of TBM or community reading corner, based on socio-cultural values that are designed to know people's interest in reading by using an approach to the socio-cultural values of the communities where TBM is located. Purpose The implementation of community reading corner is intended to provide access to learning facilities that provide reading service, widespread and affordable by the community easily. Because community of reading corner has a role as a source of learning for young children, a source of information for parents in fostering early childhood, and recreational and educational facilities for the community.
\end{abstract}

Keywords: TBM, Literacy, early childhood, learning resources, recreation-education

\begin{abstract}
Abstrak
Literasi merupakan kemampuan mengakses, memahami, dan menggunakan sesuatu secara cerdas melalui berbagai aktivitas, antara lain membaca, melihat, menyimak, menulis, dan berbicara. Tujuan memilih pengadaan taman baca masyarakat ini melihat dari minat baca masyarakat panduman sangat minim terutama di kalangan masyarakat remaja dan anak-anak.Dengan adanya keinginan untuk meningkatkan literasi nantinya akan dapat meningkatkan kesejahteraan hidup masyarakat itu sendiri. Contohnya adalah dengan adanya TBM atau taman bacaan masyarakat, berbasis nilai sosial budaya yang dirancang untuk memenuhi minat baca masyarakat dengan menggunakan pendekatan nilai-nilai sosial budaya masyarakat tempat TBM berada. Tujuan Penyelenggaraan taman bacaan masyarakat dimaksudkan untuk menyediakan akses sarana pembelajaran yang menyediakan dan memberi layanan bahan bacaan yang merata,meluas, dan terjangkau oleh masyarakat dengan mudah dan murah. Sebab taman baca masyarakat berperan sebagai sumber belajar anak-anak usia dini, sumber informasi bagi para orang tua dalam membina anak usia dini, dan sarana rekreasi-edukasi bagi masyarakat.
\end{abstract}

Kata kunci: TBM, Literasi,anak usia dini,sumber belajar,rekreasi-edukasi

\section{PENDAHULUAN}

Literasi atau dalam bahasa Inggris literacy merupakan landasan untuk kegiatan belajar sepanjang hayat. Hal ini sangat penting untuk pembangunan sosial dan manusia demi meningkatkan kemampuan agar dapat merubah hidup ke arah yang lebih baik. Literasi menurut
Kemendikbud (2016: 2) adalah kemampuan mengakses, memahami, dan menggunakan sesuatu secara cerdas melalui berbagai aktivitas, antara lain membaca, melihat, menyimak, menulis, dan berbicara.

Kemunduran kegiatan atau minat pada literasi saat ini sangat berpengaruh, terlebih pada usia anak-anak hingga yang sedang menempuh pendidikan. Kegiatan literasi mulai 
terkikis disebabkan lebih asik dengan gadget masing-masing yang didalamnya menawarkan akses keberbagai jangkauan dengan lebih mudah dan cepat. Namun literasi masih dirasa perlu karena dengan menanamkan budaya literasi berarti menanamkan budaya membaca dan sekaligus mengkaji atau menganalisis apa yang telah dibaca.

Kegiatan membaca saat ini sangat sulit untuk diterapkan selain karena semangat membaca yang kurang, keberadaan buku bacaan sangat sulit ditemui dan didapatkan. Masyarakat yang menyatakan bahwa,berseminya budaya baca adalah kebiasaan membaca,sedangkan kebiasaan membaca terpelihara dengan tersedianya bahan bacaan yang baik, menarik,memadai, baik jenis, jumlah maupun mutunya. Inilah sebuah formula yang secara ringkas untuk mengembangkan minat dan budaya baca (Saepudin, 2016: $6)$.

Taman bacaan masyarakat merupakan sumber belajar yang melaksanakan fungsi perpustakaan yang menyediakan bahan informasi yang dimanfaatkan masyarakat untuk meningkatkan minat baca dan melek informasi. Keberadaa taman bacaan masyarakat ini diharapkan berfungsi untuk: 1) menumbuhkan minat baca; 2) memperkaya pengalaman belajar; 3) menumbuhkan kegiatan belajar mandiri; 4) memperluas wawasan masyarakat; 5) tempat belajar sepanjang hayat (Lasa Hs, 2009: 331)

Penyelenggaraan taman bacaan masyarakat dimaksudkan untuk menyediakan akses sarana pembelajaran yang menyediakan dan memberi layanan bahan bacaan yang merata,meluas, dan terjangkau oleh masyarakat dengan mudah dan murah.TBM adalah singkatan dari taman bacaan masyarakat yang berbasis nilai sosial budaya yang dirancang untuk memenuhi minat baca masyarakat dengan menggunakan pendekatan nilai-nilai sosial budaya masyarakat tempat TBM berada (Kemendikbud, 2012).

Berdasar dari fenomena yang ada didesa Panduman serta dari kesadaran akan pentingnya literasi akhirnya timbul gagasan untuk membangun fasilitas Taman Baca di Desa Panduman dengan tujuan untuk menambah motivasi membaca masyarakat yang ada didesa Panduman terlebih lagi bagi mereka yang sedang menempuh jenjang pendidikan.

Dengan hadirmnya taman bacaan masyarakat di desa Panduman ini masyarakat menjadi memiliki sarana belajar secara mandiri. Hal ini sesuai dengan fungsi taman bacaan masyarakat yakni sumber belajar, pusat informasi, dan pusat rekreasi Berbasis belajar. Dengan disediakan berbagai koleksi yang selaras dengan penggunanya baik berupa buku, majalah, surat kabar ataupun media lain maka taman bacaan ini berfungsi sebagai pusat belajar. Masyarakat bisa memanfaatkan koleksi yang disediakan taman bacaan sebagai sumber belajar. Berdasarkan hal tersebut, dapat dikatakan taman bacaan masyarakat ini dapat memperluas wawasan masyarakat penggunanya dan sebagai media belajar sepanjang hayat. Oleh karena itu, segmentasi dari taman bacaan masyarakat ini mulai dari anak-anak dan remaja sampai oranng tua. Untuk segmentasi ini, taman bacaan masyarakat berfungsi sebagai pusat informasi.

\section{METODE}

Metode pelaksanaan dalam penyediaan taman baca masyarakat berisikan tentang prosedur yaitu perencanaan, pembuatan, proses, evaluasi, dan keberlanjutan dari program penyediaan taman baca masyarakat Panduman. Prosedur yang pertama dilakukan adalah perencanaan, yaitu dengan adanya sebuah kegiatan musyawarah bersama beberapa perangkat desa serta anggota karang taruna di desa Panduman untuk saling memberikan ide bagaimana memunculkan minat baca masyarakat. Prosedur yang kedua adalah pembuatan, setelah melakukan kegiatan musyawarah didapatkan beberapa ide menarik dan berlanjut pada tahapan pembuatan atau penerapan dari sebuah perencanaan yaitu dengan membangun sebuah taman bacaan. Mulai dari mengumpulkan buku, mendekorasi ruangan, pendataan buku dan beberapa hal lainnya.

Selanjutnya beralih pada proses, mengingat tujuan utama dari kegiatan ini adalah untuk memunculkan minat baca dan meningkatkan literasi di desa Panduman maka resmi dibuat dan sudah dapat digunakan sebuah ruangan berisi beberapa buku yang bisa dibaca ataupun dipinjam oleh masyarakat. Penyediaan taman bacaan masyarakat yang dilakukan yaitu dengan memberikan fasilitas baca seperti ruang baca, buku-buku gratis yang dapat dibaca atau dipinjam oleh masyarakat serta memberikan pengetahuan terkait administrasi peminjaman buku-buku demi terjaganya fasilitas yang telah ada. Sosialisasi terkait keberadaan TBM ini dilakukan melalui launching TBM itu sendiri dan melalui kegiatan bimbingan belajar yang telah menjadi kegiatan rutin setiap malam senin-jumat. Yang terakhir adalah proses evaluasi, dengan adanya taman baca yang masih baru di lingkungan masyarakat maka sangat diperlukan sebuah 
evaluasi untuk lebih meningkatkan manfaat adanya taman bacaan serta untuk meningkatkan kualitas taman bacaan masyarakat tersebut.

\section{HASIL DAN PEMBAHASAN}

Taman baca masyarakat merupakan hal yang sangat penting dalam menunjang pengetahuan dan wawasan masyrakat dan juga menjadi tempat atau wadah yang di kelola oleh pihak desa dengan bersinergi dengan remaja desa paduman dalam rangka memberikan akses bagi masyrakat dalam menyediakan bahan bacaan yang mewujudkan konsep pembelajaran sepanjang hanyat. Jadi sasaran dari terciptanya taman baca masyarakat ini adalah seluruh kalangan masyarakat panduman, bukan hanya tempat untuk mencari pengetahuan tetapi akan terciptanya kerukunan dan silahturrahmi antar warga masyrakat panduman dengan adanya taman baca tersebut.

\section{a. Perencanaan Taman Bacaan Masyarakat}

Perencanaan adalah proses yang mendefinisikan tujuan dari organisasi, membuat strategi digunakan untuk mencapai tujuan dari organisasi, serta mengembangkan rencana aktivitas kerja yang akan dilakukan. Perencanaan merupakan proses-peroses yang penting dari semua fungsi manajemen sebab tanpa perencanaan fungsi pengorganisasian, pengontrolan maupun pengarahan tidak akan dapat berjalan. Sepertihalnya perencanaan dalam pengadaan taman baca masyarakat panduman harus mendapat persetujuan dari pihak-pihak yang akan menunjang dalam menyukseskan pengadaan taman baca masyarakat dengan cara diskusi dan musyarawarah berekenaan apa saja yang di butuhkan dalam pengadaan taman baca tersebut, sehingga dengan adanya musyawarah tersebut program kerja ini bisa berkelanjutan dan pemanfaatanya berkesinambungan dan berkembang sesuia tujuan yang diinginkan.

Dengan berdiskusi dengan pihak terkait terutama dengan kepala desa panduman mengenai penyediaan taman baca masyarakat ( TBM ) guna melestarikan budaya membaca sebab membaca dapat memperluas wawasan masyarakat penggunanya dan sebagai media belajar sepanjang hayat. Dengan persetujuan dari pihak desa kemudian penentuan penempatan tempat taman baca masyarakat di desa panduman serta apa saja yang akan di butuhkan dalam penyediaan taman baca tersebut. Pembentukan strutur pengelola taman baca masyrakat tersebut sehingga taman baca terkelola dengan baik dan bermanfaatan secara berkesinambungan bagi masyarakat panduman terutama anak-anak yang masih di bangku pendidikan.

Dengan adanya persetujuan berbagai pihak yaitu kepala desa panduman dan kami mulai pembuatan taman baca tersebut dengan konsep yang sekiranya memberikan daya tarik pagi pembaca dan memberikan kesan kenyamanan untuk pembaca, dengan bersinergi dengan karang taruna panduman kami mulai mendisain taman baca tersebut sesuai dengan konsep yang telah disepakati. Sehingga pengunjung menjadi betah mengunjungi taman baca tersebut seperti halnya menambah lukisan dan katakata yang memberikan motifasi bagi pembacanya.

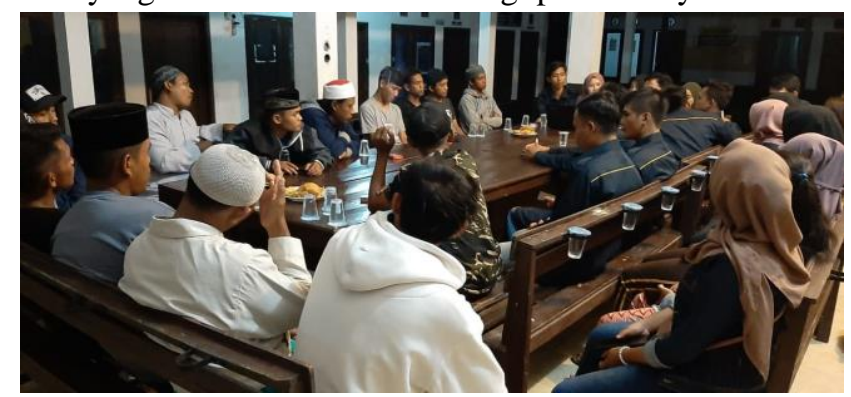

Gambar 1. Diskusi bersama karang taruna mengenai pembuatan taman baca masyrakat

Pengembangan taman bacaan masyarakat perlu diperhatikan mengenai susunan organisasi dan sarana yang harus dimiliki. Susunan organisasi taman bacaan sekurangkurangnya terdiri atas: a. Ketua, mempunyai tugas: (a) memimpin TBM, (b) menyusun dan menetapkan program, (c) memajukan dan mengembangkan TBM, (d) melakukan hubungan kerjasama, dan (e) mengelola keuangan, b. Urusan Administrasi dan Teknis, mempunyai tugas: (a) mengurus administrasi dan surat menyurat, (b) mengadakan seleksi dan pengadaan bahan bacaan, (c) melaksanakan pengolahan bahan bacaan, dan (d) melaksanakan pengembangan bahan bacaan, c. Urusan Layanan, mempunyai tugas: (a) membuat tata terib, (b) memberikan layanan TBM, dan (c) melaksanakan administrasi keanggotanaan.

\section{b. Tahapan pembuatan TBM}

Tahapan adalah cara melakukan seseorang dengan pengerjaan atau proses sehinga menjadikan benda atau yang di inginkan. Sesuai dengan hasil diskusi mengenai apa saja yang dibutuhkan sepertihalnya rak buku, buku bacaan, dan lain sebagainya yang menunjang adanya taman baca masyarakat dan disetujui dari berbagai pihak mengenai 
pengadaan taman baca dengan di dukung oleh kepala desa panduman akhirya kami bekerja sama dengan karang taruna untuk mendekorasi dengan sedemikian rupa agar taman baca masyrakat tersebut menarik bagi pengunjung. Dari pewarnaan dinding hingga penambaan lukisan yang terkesan meberikan hal yang tidak monoton bagi para masyarakat yang berkunjung di taman baca yang berada di balai desa panduman tersebut.

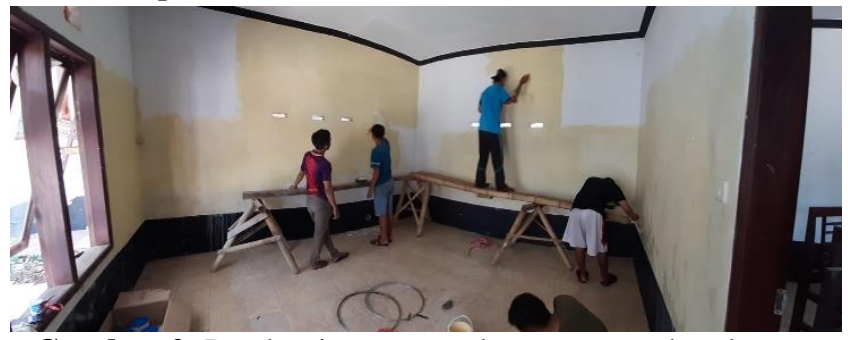

Gambar 2. Pendesainan taman baca masyarakat dengan bantuan karang taruna desa panduman

\section{c. Proses pengolahan bahan bacaan}

Pengolahan adalah suatu perbuatan, cara, atau proses mengolah sesuatu hal.Sebuah taman bacaan akan berjalan sesuai dengan tujuan, peran dan fungsinya apabila koleksi yang dimilikinya dikelola dengan baik. Manajemen koleksi merupakan area kunci dari tangung jawab seorang pengelola taman bacaan. Koleksi sendiri dapat didefiniskan sebagai sebuah bahan pustaka atau sejenisnya yang dikumpulkan, dikelola, dan diolah dengan criteria tertentu. Dengan pengelolaan taman baca masyrakat dan bahan bacaannya kami bersinergi dengan karang taruna Panduman yaitu Repandu yang artinya Remaja panduman, kami memberikan pelatihan dalam administrasi pembukuan bahan bacaan dan memilah dan mengelompokkan sedemikian rupa sesuia dengan jenis bacaan dan sesuai dengan kalangan pembacanya seperti anak-anak, remaja, dan orang tua dan ada juga beberapa buku untuk perguruan tinggi, karena Fungsi taman bacaan adalah menyediakan koleksi yang mampu menunjang proses belajar masyarakat. Sebayak apapun koleksi yang dimiliki oleh taman bacaan belum bisa dimanfaatkan/ didayagunakan oleh masyarakat apabila koleksi tersebut belum diolah sehingga siap disajikan kepada para penggunanya. Pengelolaan koleksi yang baik akan menentukan sukses tidaknya sebuah program taman bacaan. Karena tanpa dikelola dengan baik, maka koleksi akan tetap menjadi kumpulan atau tumpukan buku yang tidak bermakna.

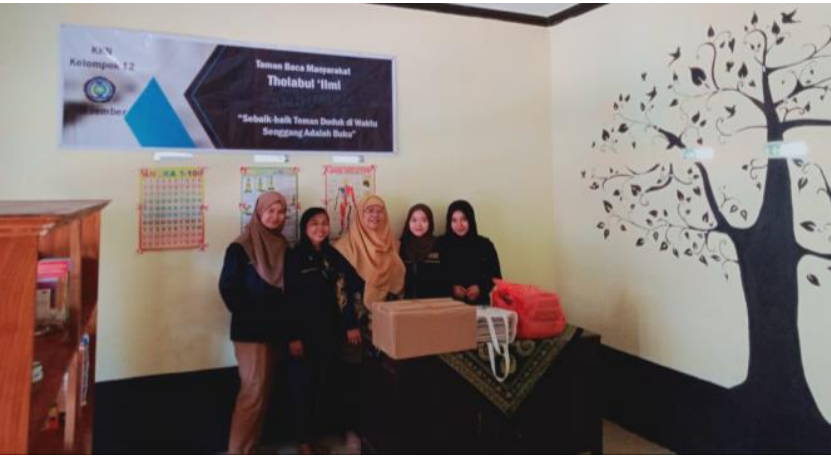

Gambar 3. Pengelompokan bahan bacaan sesuai kategori buku di dampingi dosen pembimbing lapangan

\section{d. Evaluasi Taman Baca Masyarakat Panduman}

Evaluasi adalah pengukuran dan perbaikan dalam kegiatan yang dilaksanakan, seperti membandingkan hasilhasil kegiatan yang dibuat. Tujuannya agar rencana-rencana yang telah dibuat untuk mencapai tujuan yang ditetapkan dapat terselenggarakan. Setelah taman baca selesai di bentuk dan bahan bacaan yang telah di kelompokkan sesuai dengan kategorinya dan mulai dipergunakan dengan semestinya tetapi dengan terbentuknya taman baca tersebut sebelum di sosialisasikan kepada masyrakat maka di butuhkan evaluasi terlebih dahulu perihal apa yang masih kurang dan bagai mana untuk menyelesaikannya, dengan adanya taman baca yang masih baru di lingkungan masyarakat maka sangat diperlukan sebuah evaluasi untuk lebih meningkatkan manfaat adanya taman bacaan serta untuk meningkatkan kualitas taman bacaan masyarakat.

\section{e. Sosialisasi dan keberlanjutan Taman Baca Masyarakat}

Sosialisasi adalah proses penanaman atau transfer kebiasaan atau nilai dan aturan dari satu generasi ke generasi lainnya dalam sebuah kelompok atau masyarakat seperti halnya sosialisai taman baca masyarakat kepada kalangan masyarakat terutama kepada kalangan anak muda panduman dan anak-anak yang masih di bangku pendidikan. Sosialisasi taman baca masyarakat ini hal yang pertama kami mengadakan kegiatan bimbingan belajar yaitu dari hari senin sampai hari jum'at yang rutin dilaksanakan. Antusias berbagai kalangan anak-anak dalam pengadaan bimbingan belajar ini kami mendapatkan dukungan yang sangan baik dari masyarakat panduman. kemudian setelah taman baca masyarakat selesai dan siap di pergunakan oleh masayarakat kami mengundang berbagai pihak untuk meresmikan taman baca masyrakat tersebut yaitu dari kalangan perangkat desa, semua dusun, semua kepala sekolah yang ada di desa 
panduman dan juga karang taruna, sekaligus mensosialisasikan adanya taman baca dan pentingnya budaya membaca.

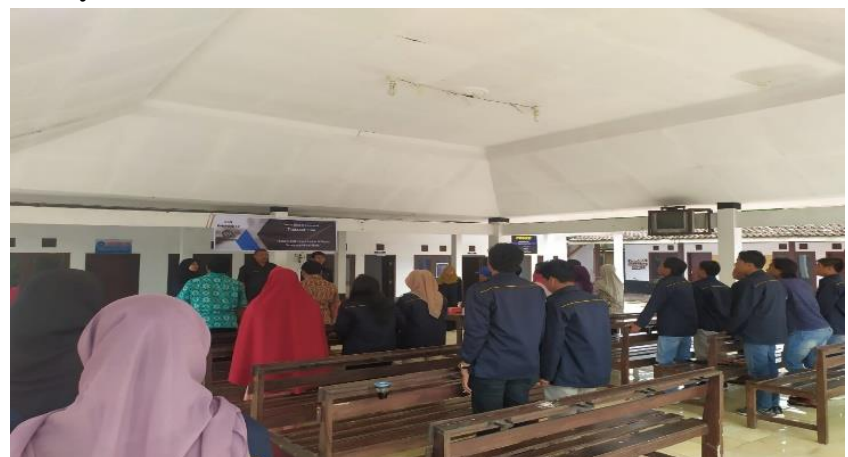

Gambar 4. Sosialisasi taman baca masyarakat dibalai desa Panduman

Kegiatan pengadaan Taman Baca Masyarakat dilakukan pada hari Kamis 20 Februari 2020 bertempat di Polindes Desa Panduman Kecamatan Jelbuk. Pembukaan TBM diresmikan oleh kepala desa Panduman dengan melakukan pengguntingan pita serta disaksikan oleh beberapa perangkat desa dan beberapa kepala sekolah dari sekolah yang ada di desa Panduman.

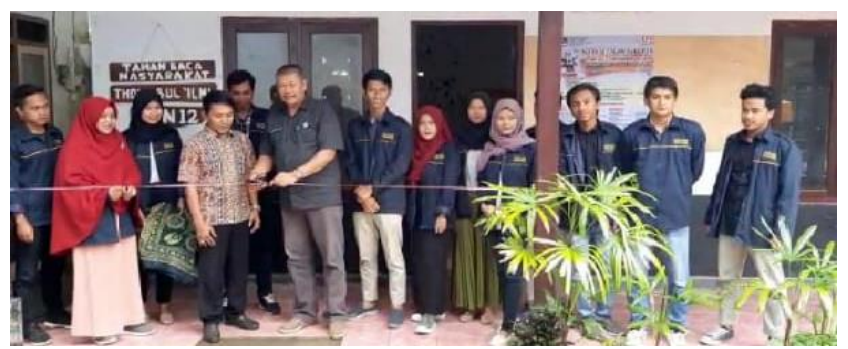

Gambar 5. Pengguntingan pita oleh kepala desa Panduman untuk meresmikan TBM

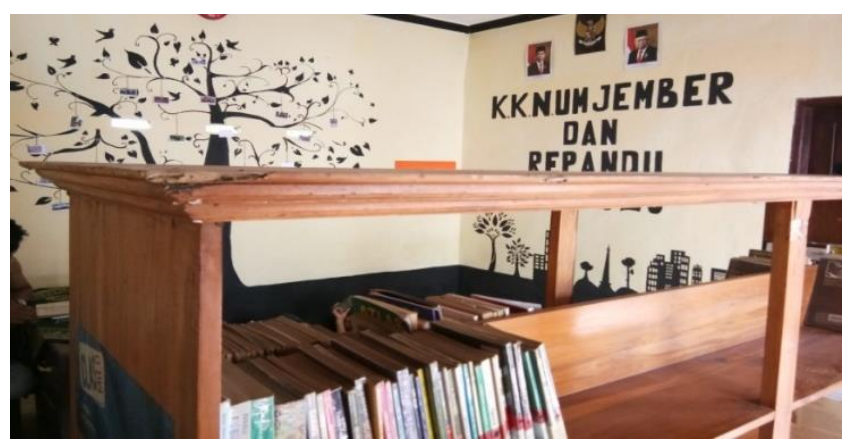

Gambar 6. Kondisi bagian dalam Taman Baca Masyarakat Tholabul'ilmi
Taman Baca Masyarakat diberi nama Tholabul'ilmi yang berarti bahwa menuntut ilmu itu wajib bagi setiap muslim/muslimah sejak dari ayunan hingga liang lahad. Itulah dalil kewajiban tiap manusia untuk menimba ilmu. Dari dalil di atas, dapat dimaknai bahwa ilmu itu luas, ilmu itu banyak, tiada batasnya.Diharapkan dengan adanya Taman Baca Masyarakat ini dapat meningkatkan kemampuan keberaksaraan dan keterampilan membaca, menumbuh kembangkan minat dan kegemaran membaca, membangun masyarakat membaca dan belajar, mendorong mewujudkan masyarakat pembelajar sepanjang hayat, mewujudkan kualitas dan kemandirian masyarakat yang berpengetahuan, berketerampilan, berbudaya maju, dan beradab. Dari tujuan dan fungsi tersebut di atas dapat disimpulkan bahwa dengan adanya taman bacaan masyarakat diharapkan masyarakat dapat meningkatkan pengetahuan dan keterampilannya dalam segala bidang.

Adapun hasil yang dicapai dari kegiatan pengabdian kepada masyarakat ini adalah telah terdapatnya ruang baca yang dilengkapi rak, buku, meja, kursi sebagai fasilitas utama dari taman baca. Adanya fasilitas buku yang meliputi : buku pelajaran untuk SD, SMP SMA, Perguruan Tinggi, buku cerita, novel, ada pula buku umum seperti buku ilmu pertanian, kesehatan, hukum pemerintahan desa, korupsi, tinda pidana, dan sebagainya. Serta telah tersusun struktur pengelolaan TBM dan administrasi pembukuan untuk TBM.

Kemudian telah terciptanya taman baca masyarakat tersebut dengan berbagai penunjang didalamnya dan sosialisasi keberbagai pihak lapisan masyarakat dan di bantu oleh karang taruna akhirnya taman baca masyarakat tersebut bisa di pergunakan sebagaimana mestinya sepertinya halnya perangkat desa yang memiliki kekosongan waktu bisa beritirahat di taman baca tersebut sambih membaca dan anak-anak sekolah setempat ketika tidak ada kegiatan mereka mendatangi taman baca tersebut untuk menikmati bacaan yang telah di suguhan dengan berbagai macam bahan bacaan dan menambah pengetahuan dan wawasan bagi masyarakat panduman terutama anak-anak.

\section{KESIMPULAN}

Adanya Taman Baca Masyarakat Tholabul'ilmi ini telah membantu berseminya budaya baca dan semangat membaca. Kebiasaan membaca akan terpelihara dengan tersedianya bahan bacaan yang baik, menarik, memadai, baik jenis, jumlah maupun mutunya. Inilah sebuah formula

http://comdev.pubmedia.id | Indonesian Journal Publisher | http://idpublishing.org 
yang secara ringkas untuk mengembangkan minat dan budaya baca.

Masyarakat di desa Panduman hendaknya mampu saling menyemangati dalam membaca proses meningkatkan literasi membaca. Karena dari membaca kita dapat membuat kehidupan menjadi lebih baik.

\section{DAFTAR PUSTAKA}

Damayani.N,Silvana.T. ( 2017 ). Pengembangan Taman Bacaan Masyarakat Di Desa Sindangkerta Kecamatan Cipatujah Kabupaten Tasikmalaya. Program Studi Ilmu Perpustakaan Fakultas Ilmu Komunikasi Universitas Padjadjaran

Saepudin, E. (2016). Tingkat Budaya MembacaMasyarakat (Studi Kasus Pada MasyarakatDi Kabupaten Bandung).Jurnal KajianInformasi Dan Perpustakaan,3(2), 276.Retrieved from http://jurnal.unpad.ac.id/jkip

Sani.A,Suwanto.A. ( 2018 ). Pembinaan Minat Baca Masyarakat Melalui Pembangunan Taman Bacaan Masyarakat Desa Kemasan Klepu, Semarang, Jawa Tengah. Program Studi Ilmu Perpustakaan Fakultas Ilmu Budaya, Universitas Diponegoro.

Kemendikbud. (2012). Pedoman penyelenggaraan program percontohan TBM berbasis nilai sosial masyarakat. Makasar: BPPNFI.

Kemendikbud. (2006). Permendikbud Nomor 22Tahun 2006Tentang Standar Isi. Jakarta: Kementerian Pendidikan dan Kebudayaan RI.

Lasa Hs. (2009). Kamus Kepustakawanan Indonesia. Yogyakarta: Pustaka Book Publisher 